\title{
ANALISA DAN PERANCANGAN SISTEM INFORMASI TRANSAKSI DAN PERSEDIAAN PADA TOKO BANGUNAN UD. ROMI PADANG MENGGUNAKAN BAHASA PEMROGRAMAN PHP DAN DATABASE MYSQL
}

\author{
Muhammad Ikhlas \\ Universitas Putra Indonesia YPTK Padang, Indonesia \\ mhdikhlas@upiyptk.ac.id
}

\begin{abstract}
Abstrak
Kemajuan teknologi saat ini berpengaruh besar terhadap kegiatan usaha, tidak hanya usaha tingkat atas saja, tetapi juga telah menyentuh usaha kecil dan menengah. Kebutuhan akan penggunaan teknologi terutama komputer dalam melakukan pengolahan data usaha telah menjadi hal yang wajib bagi setiap usaha agar mampu berkompetisi dengan bentuk usaha lainnya, terutama usaha yang sejenis. Tidak terkecuali pada usaha toko bangunan UD. Romi di Kota Padang. Saat ini pencatatan dan pengolahan data transaksi baik penjualan maupun persediaan masih dilakukan dengan pembukuan. Sehingga sering kali terjadi kesalahan dalam pencatatan transaksi. Oleh karena itu, melalui proses analisa dan desain dalam pengembangan sistem informasi transaksi dan persedian dengan pemodelan UML, serta implementasi pemrograman PHP dan beberapa kali pengujian terhadap program, dapat membantu pemilik dan karyawan dalam mengelola data transaksi dengan baik, sehingga kegiatan usaha menjadi lebih efektif dan efisien.
\end{abstract}

Kata kunci: Sistem Informasi , Transaksi, Persediaan, PHP, MySQL

\section{PENDAHULUAN}

Aktifitas kegiatan usaha dewasa ini dapat dikatakan sudah mulai beralih dari sistem manual ke otomasi. Kemudahan, efektifitas dan efisiensi menjadi hal yang mengubah pandangan tersebut. Usaha Dagang (UD) Romi yang berada di Kota Padang yang menjual berbagai bahan bangunan di kawasan pemukiman Siteba, Nanggalo, Padang mencatatkan ratusan transaksi perhari, sehingga cara lama tidak efektif dalam dalam mengolah data barang di toko tersebut. Sistem persediaan dan penjualan barang yang dilakukan secara manual mengakibatkan kesulitan dalam pengolahan data dan pencarian data, karena banyaknya item barang yang tidak tersusun rapih berdasarkan kode (Sudarsono \& Erniyanti, 2017).

Pengolahan data yang diperlukan dalam toko bangunan UD. Romi dapat berupa pencatatan transaksi penjualan serta persediaan barang atau bahan bangunan. Setiap data yang dimasukkan akan tersimpan dengan baik ke dalam database, sehingga setiap kali adanya transaksi maka akan cepat dapat ditelusuri dan diketahui harga serta ketersediannya. Pemilik tidak takut lagi data penjualan tidak tercatat ke dalam buku pembelian, karena semua data sudah tersimpan ke dalam database.

Dalam analisa dan perancangan sistem informasi ini menggunakan bahasa pemodelan UML (Unified Modeling Language) dan pengembangan aplikasinya menggunakan bahasa pemrograman PHP dan database MySQL. Sehingga diharapkan mampu menghasilkan laporan data penjualan dan persedian kepada pemilik usaha dalam membantu mengambil keputusan. 


\section{LANDASAN TEORI}

\subsection{Sistem Informasi}

Sistem informasi (SI) adalah kombinasi dari orang-orang, perangkat keras, perangkat lunak, jaringan komunikasi, sumber daya data, dan kebijakan serta prosedur dalam menyimpan, mendapatkan kembali, mengubah, dan menyebarkan informasi dalam suatu organisasi (George M. Marakas \& James A. O'Brien, 2017). Kualitas informasi yang baik dapat diukur terhadap tiga faktor yaitu relevansi atau kecocokan data dan informasi, tepat waktu dan akurat.

Akurasi berarti bahwa informasi bebas dari kesalahan, Relevansi berarti bahwa informasi benarbenar berguna bagi suatu tindakan keputusan yang dilakukan oleh seseorang. Tepat waktu berarti bahwa informasi datang pada saat dibutuhkan sehingga bermanfaat untuk pengambilan keputusan (Abdul Kadir \& Terra Ch. Triwahyuni, 2013)

\subsection{Rekayasa Perangkat Lunak}

\subsubsection{Pemodelan dan UML}

Menurut Rosa A. S dan M. Shalahuddin (2015) pemodelan adalah gambaran dari realita yang simpel dan dituangkan dalam bentuk pemetaan dengan aturan tertentu. Pemodelan perangkat lunak memiliki beberapa abstaksi, misalnya sebagai berikut :
a. petunjuk yang terfokus pada proses yang dimiliki oleh sistem
b. spesifikasi struktur secara abstrak dari sebuah sistem (belum detail)
c. spesifikasi lengkap dari sebuah sistem yang sudah final
d. spesifikasi umum atau khusus sistem
e. bagian penuh atau parsial dari sebuah sistem

Salah satu bahasa pemodelan yaitu UML. Menurut Martin Fowler (2005) UML (Unified Modeling Language) yaitu keluarga notasi grafis yang didukung oleh meta-model tunggal, yang membantu pendeskripsian dan desain sistem perangkat lunak, khususnya sistem yang dibangun dengan menggunakan pemrograman berorientasi objek (OO). Pemodelan UML terdiri dari berbagai diagram, diantaranya Use Case Diagram, Class Diagram, Sequence Diagram, Activity Diagram dan diagram lainnya.

\subsubsection{Bahasa Pemrograman PHP}

Menurut Betha Sidik (2017) PHP adalah kependekan dari PHP:HyperText Preprocessor (rekursif, mengikuti gaya penamaan di *nix), merupakan bahasa utama script server-side yang disisipkan pada HTML yang dijalankan di server, dan juga bisa digunakan untuk membuat aplikasi desktop.

\subsubsection{Database MySQL}

Menurut Abdul Kadir (2010), Database MySQL tergolong sebagai DBMS (Database Management System). DBMS adalah sistem yang secara khusus dibuat untuk memudahkan pemakai dalam mengelola basis data. Sistem ini dibuat untuk mengatasi kelemahan sistem pemrosesan yang berbasis berkas (Abdul Kadir \& Terra Ch. Triwahyuni, 2013). 


\section{ANALISA DAN HASIL}

\subsection{Analisa Sistem}

Analisa sistem digunakan untuk mengetahui kelemahan dan membuatkan solusi perbaikan terhadap sistem yang sedang berjalan. Dalam melakukan analisa, digunakan beberapa diagram yaitu use case diagram, class diagram, activity diagram, dan sequence diagram.

\subsubsection{Use Case Diagram}

Use Case Diagram memberikan gambaran bagaimana interaksi antara sistem dengan pengguna atau aktor tentang aktivitas dan proses apa yang dapat dilakukan.

\section{a. Definisi Aktor}

Definisi aktor berfungsi untuk menjelaskan apa saja tugas dan tanggunjawab dari seseorang terhadap interaksi yang ada pada sistem. Berikut definisi aktor yang terlibat dalam sistem.

Tabel 1: Definisi Aktor

\begin{tabular}{|l|l|l|}
\hline No & \multicolumn{1}{|c|}{ Aktor } & \multicolumn{1}{c|}{ Deskripsi } \\
\hline 1. & Admin & $\begin{array}{l}\text { Admin bertugas untuk mengontrol sepenuhnya } \\
\text { jalannya sistem. }\end{array}$ \\
\hline 2. & Pimpinan & $\begin{array}{l}\text { Pimpinan memiliki peran untuk dapat melakukan } \\
\text { pengecekan terhadap seluruh laporan }\end{array}$ \\
\hline 3. & Bagian Gudang & $\begin{array}{l}\text { Bagian gudang bertugas sebagai pengontrol stok } \\
\text { barang dan mengentrikan jumlah penambahan } \\
\text { stok barang. }\end{array}$ \\
\hline 4. & Bagian Kasir & $\begin{array}{l}\text { Bagian kasir bertugas untuk melakukan transaksi } \\
\text { yang akan dibeli oleh pelanggan. }\end{array}$ \\
\hline
\end{tabular}

\section{b. Diagram Use Case}

Dalam Use Case Diagram sistem informasi transaksi dan persedian pada UD. Romi terdapat beberapa use case diantaranya input barang, input kategori, input karyawan, tambah barang, cek barang, transaksi, laporan kategori barang, laporan barang, laporan karyawan, laporan pertambahan stok, laporan transaksi perhari, laporan transaksi perbulan dan laporan transaksi pertahun.

Berikut gambar use case diagram sistem informasi transaksi dan persediaan pada toko bangunan UD. Romi yang dirancang. 


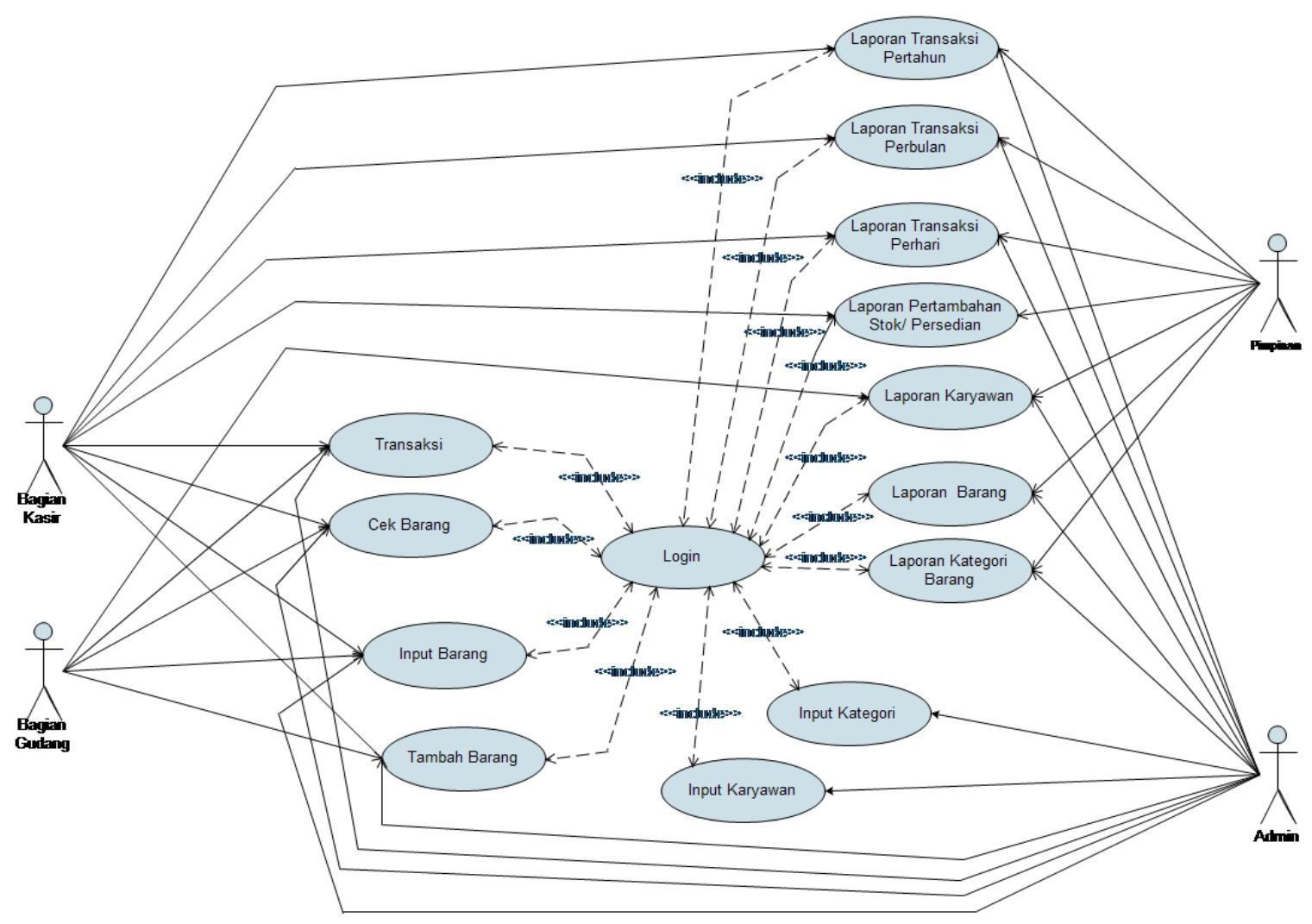

Gambar 1: Use Case Diagram

\subsubsection{Class Diagram}

Pada Class diagram ini menggambarkan struktur sistem yang mendefenisikan bagaimana kelaskelas yang akan dibuat dalam membangun sistem.

Berikut gambar class diagram pada sistem transaksi dan persediaan pada toko bangunan UD. Romi yang dirancang.

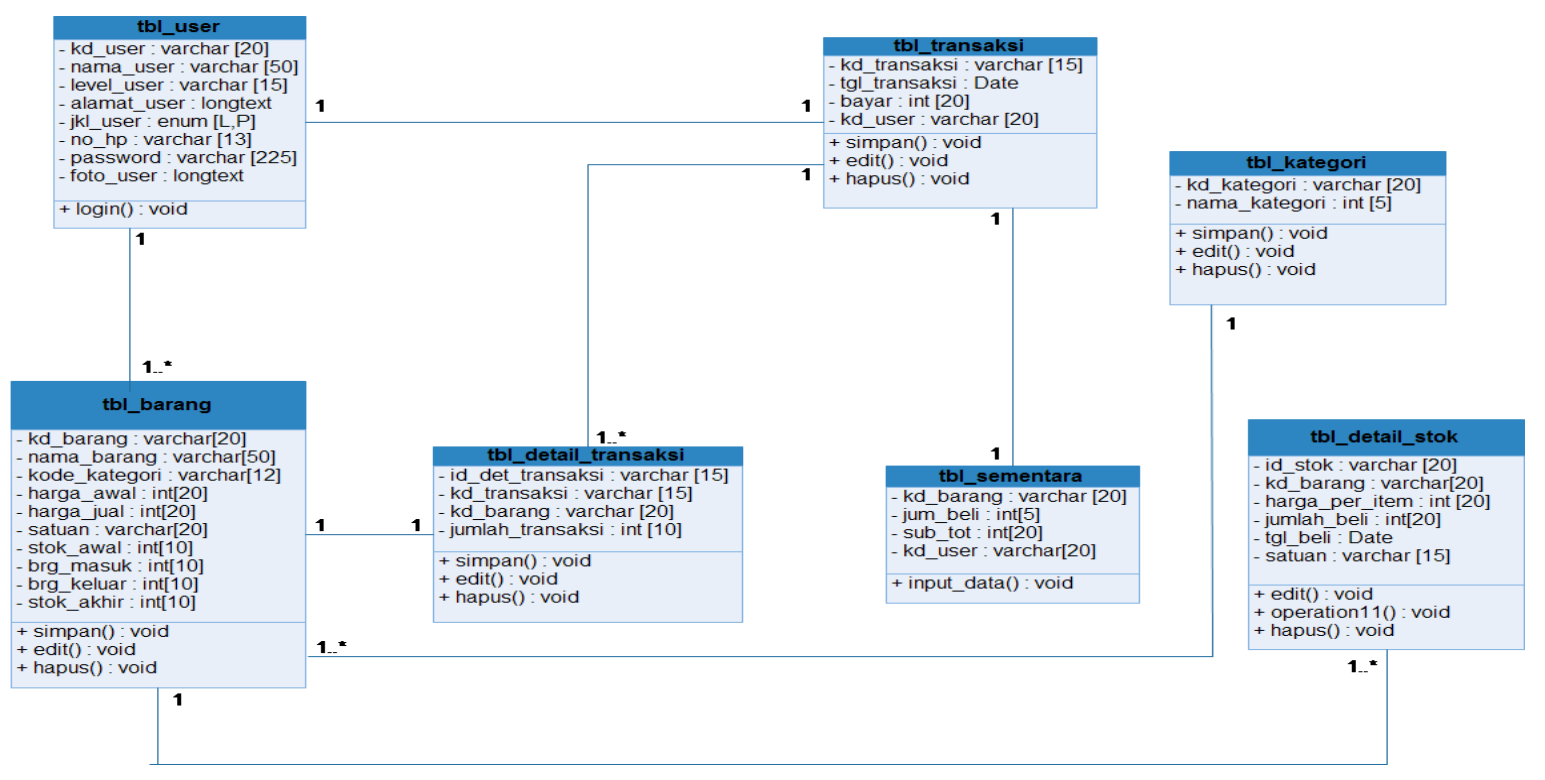

Gambar 2: Class Diagram 


\subsubsection{Activity Diagram}

a. Activity Diagram : Admin

Pada diagram aktivitas admin bertujuan sebagai user control atau administrator yang mengendalikan seluruh sistem informasi.

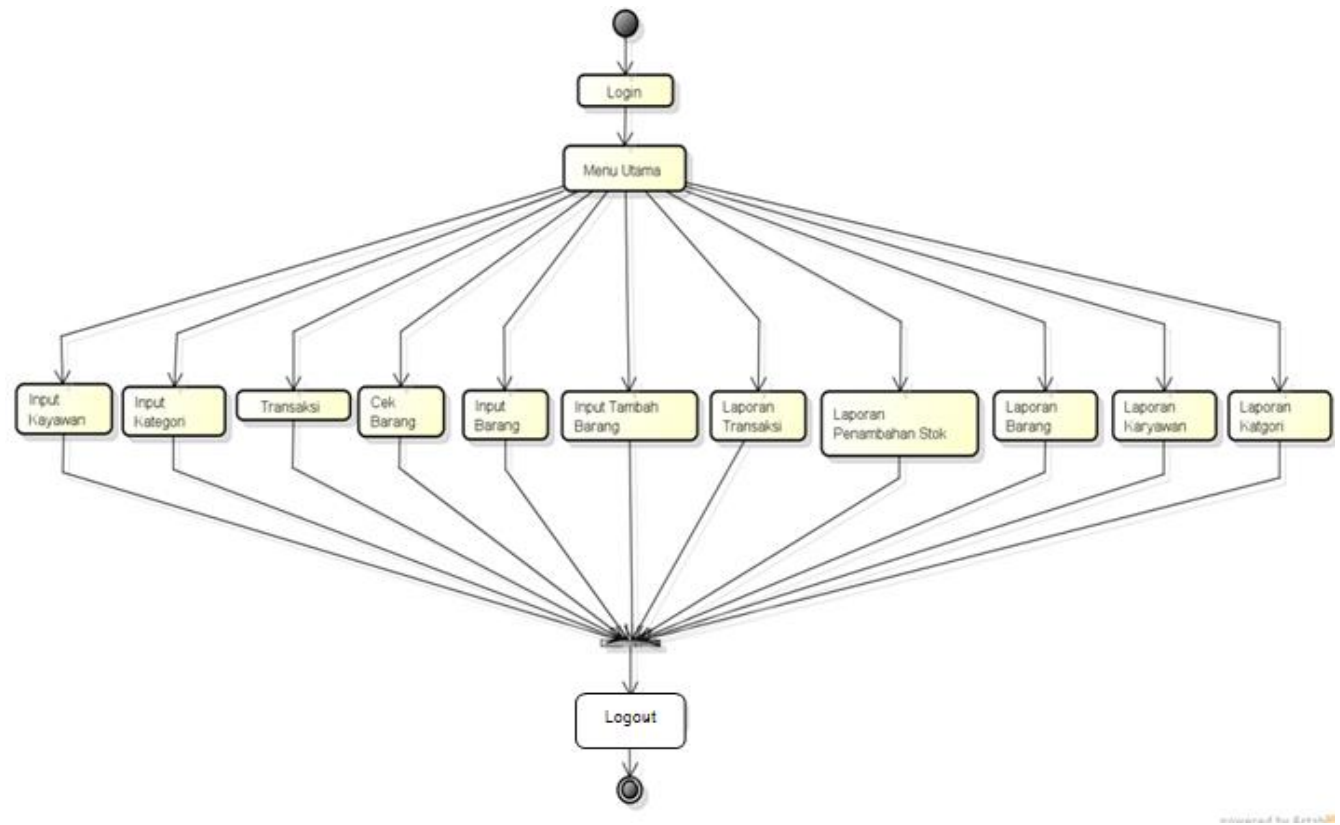

Gambar 3: Activity Diagram Admin

b. Activity Diagram : Pimpinan

Pada diagram aktivitas pimpinan bertujuan sebagai user yang menerima semua informasi yang nantinya dijadikan sebagai bahan acuan dalam mengambil keputusan, biasanya informasi yang diterima berupa laporan-laporan.

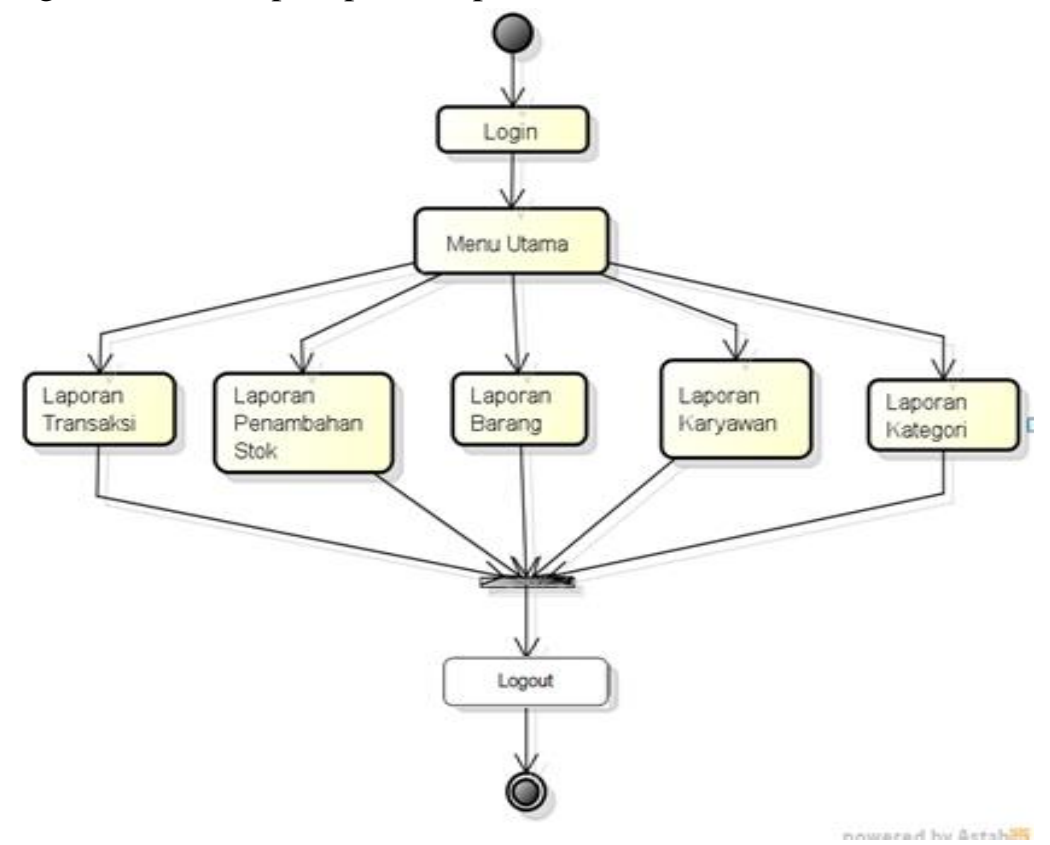

Gambar 3: Activity Diagram Pimpinan 
c. Activity Diagram : Bagian Kasir

Pada diagram aktivitas bagian kasir menjelaskan aktivitas yang apa saja yang dapat dilakukan oleh bagian kasir. Dalam hal ini beberapa aktivitas diantaranya adalah melakukan entri data transaksi, cek data barang, dan membuat laporan transaksi.

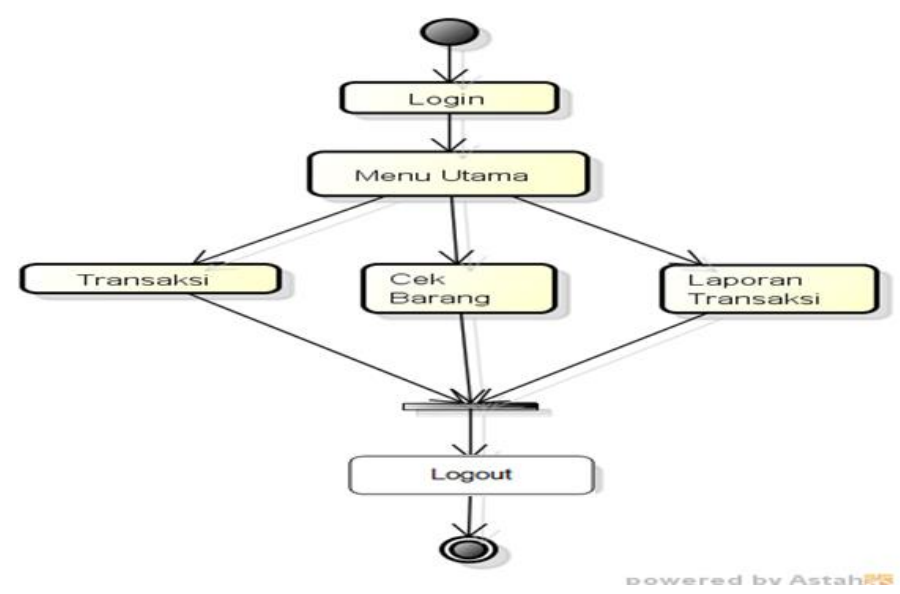

Gambar 4: Activity Diagram Bagian Kasir

d. Activity Diagram : Bagian Gudang

Pada diagram aktivitas bagian gudang menjelaskan aktivitas yang apa saja yang dapat dilakukan oleh bagian gudang. Dalam hal ini beberapa aktivitas diantaranya adalah melakukan entri data barang, menambah barang atau persediaan, dan membuat laporan penambahan stok.

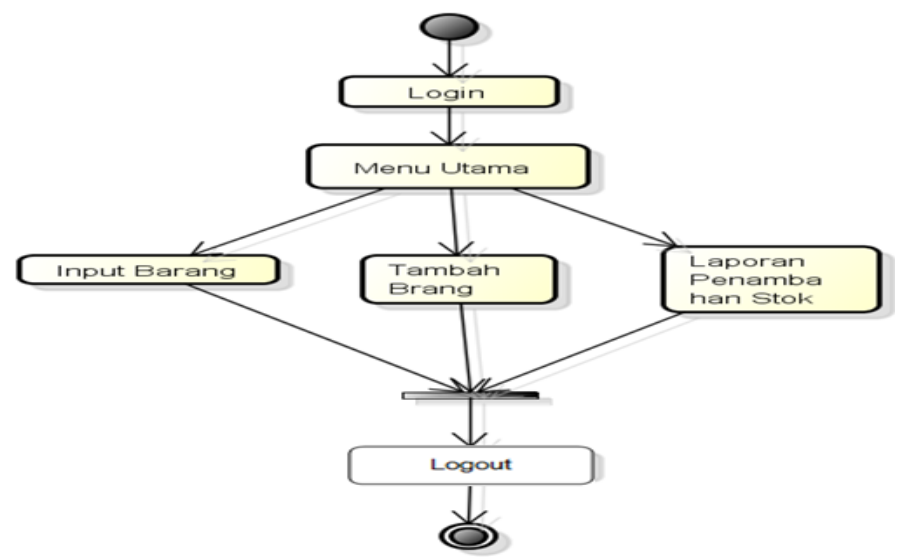

Gambar 5: Activity Diagram Bagian Gudang

\subsubsection{Sequence Diagram}

a. Sequence Diagram : Input Barang

Pada sequence diagram input barang menggambarkan bagaimana interaksi dan komunikasi pada setiap objek-objek yang ada pada sistem dalam melakukan input data barang. 


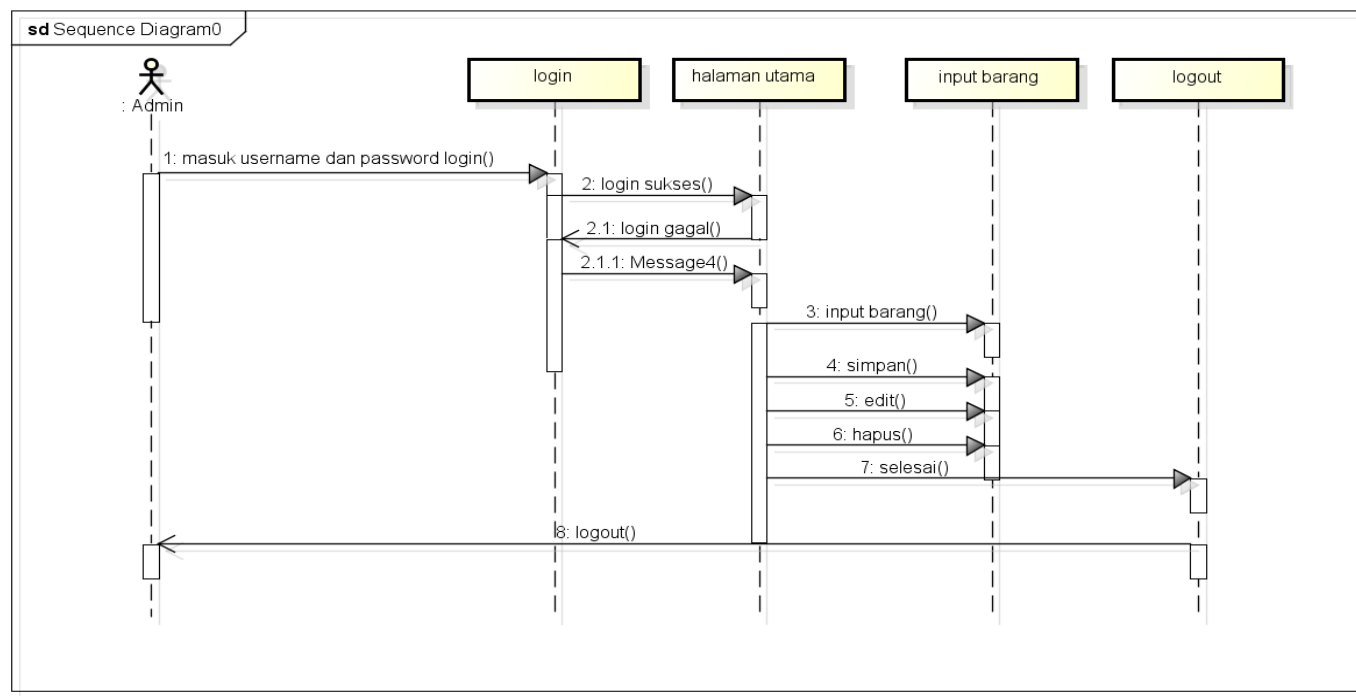

Gambar 6: Sequence Diagram Input Barang

b. Sequence Diagram : Transaksi

Pada sequence diagram transaksi menggambarkan bagaimana interaksi dan komunikasi pada setiap objek-objek yang ada pada sistem dalam melakukan transaksi.

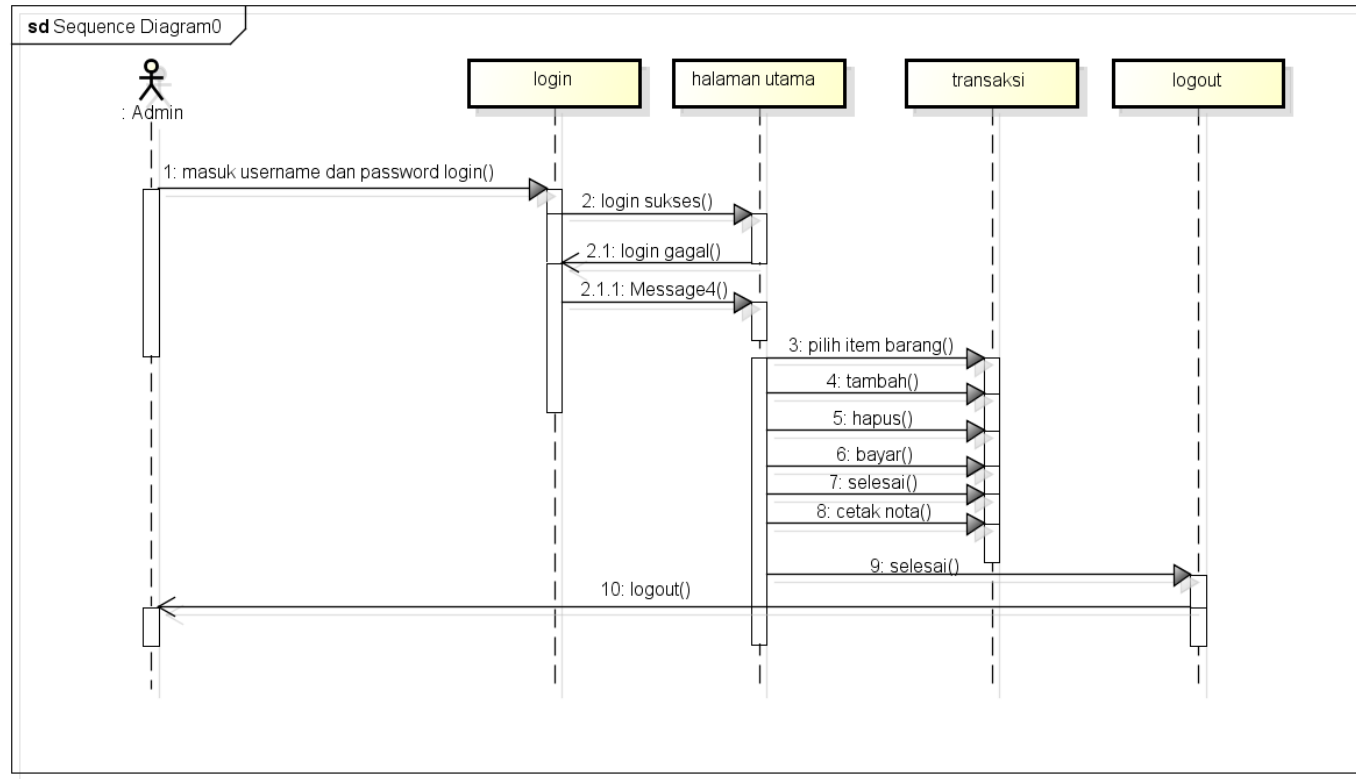

powered by Astah

Gambar 7: Sequence Diagram Transaksi

c. Sequence Diagram : Laporan Transaksi

Pada sequence diagram laporan transaksi menggambarkan bagaimana interaksi dan komunikasi pada setiap objek-objek yang ada pada sistem dalam menghasilkan laporan transaksi. 


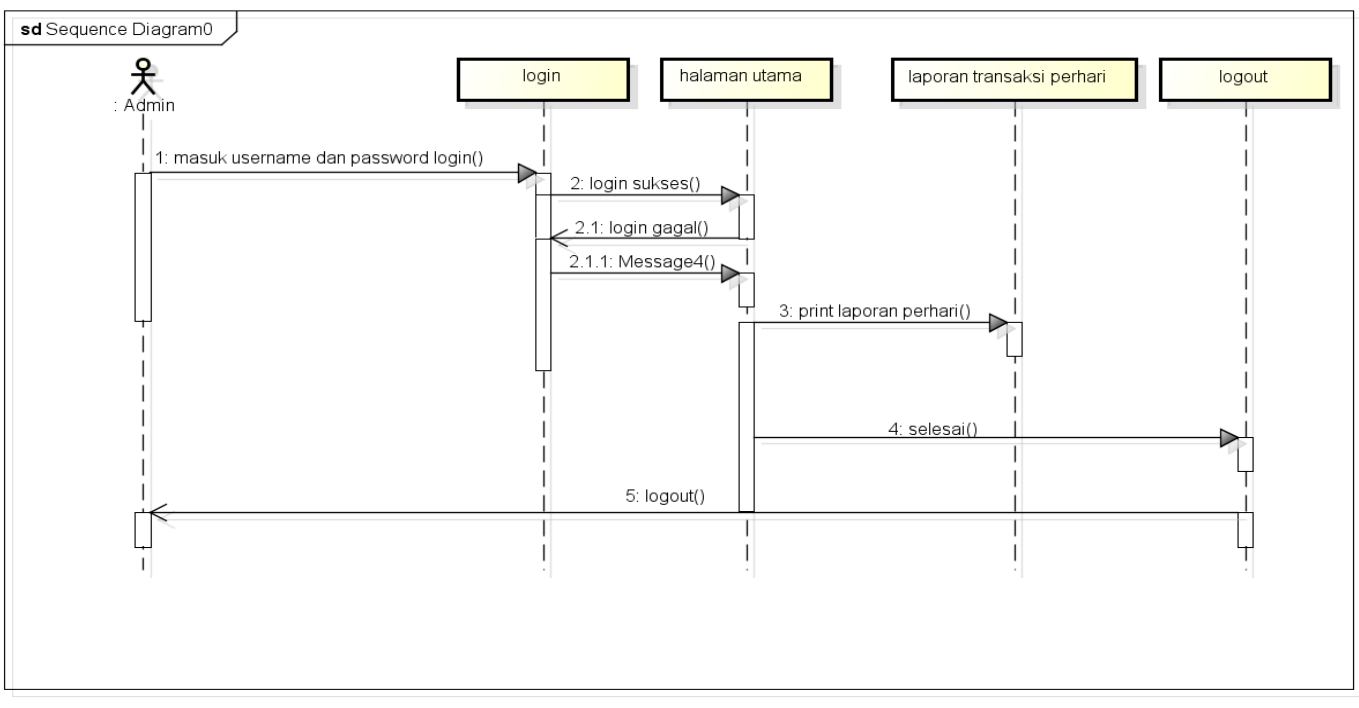

Gambar 9: Sequence Diagram Laporan Transaksi

d. Sequence Diagram : Laporan Penambahan Stok

Pada sequence diagram laporan penambahan stok menggambarkan bagaimana interaksi dan komunikasi pada setiap objek-objek yang ada pada sistem dalam menghasilkan laporan penambahan stok.

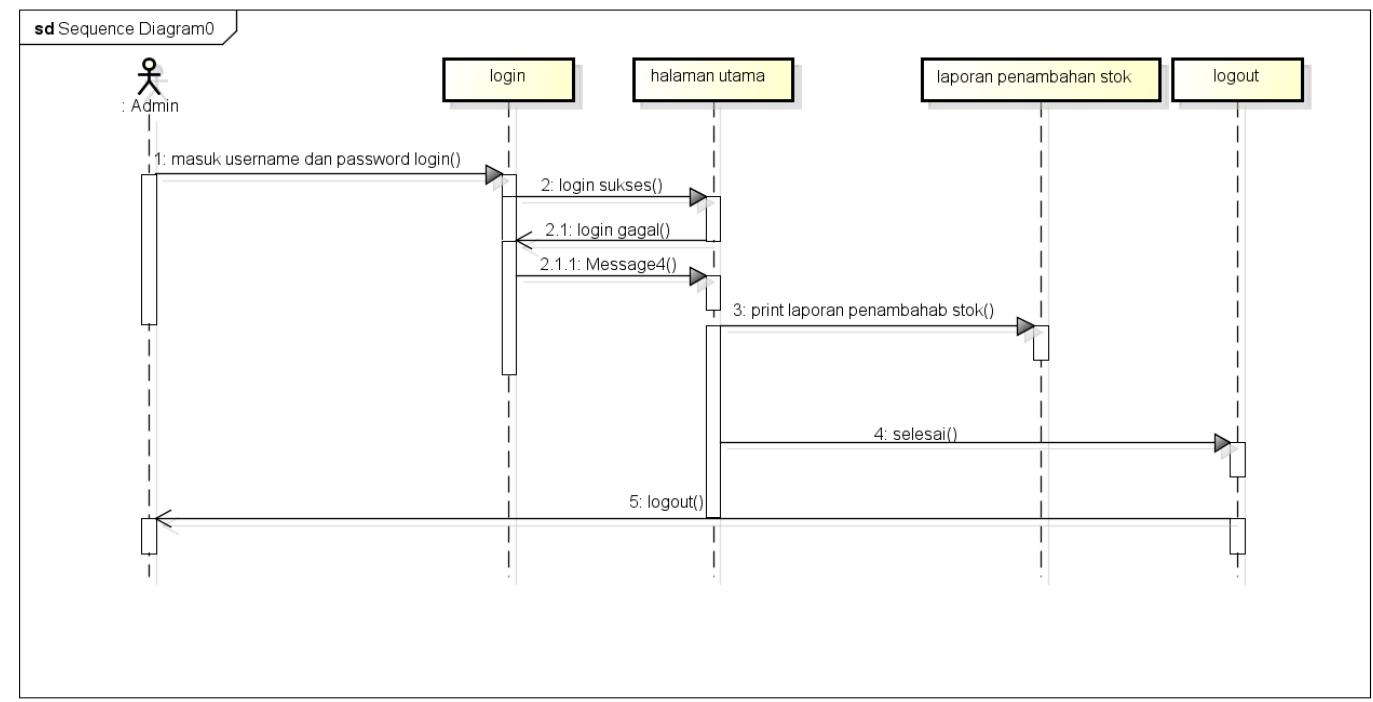

Gambar 10: Sequence Diagram Laporan Penambahan Stok

\subsection{Hasil}

Analisa dan rancangan yang telah dirancang diimplementasikan ke dalam bahasa pemrograman, sehingga menghasilkan sistem yang baru dengan spesifikasi sesuai dengan desain yang telah dibuatkan.

Berikut hasil implementasi desain dan rancangan yang telah dibuat. 
a. Halaman login sistem

Halaman login merupakan tampilan awal ketika user mengakses sistem. Dengan adanya halaman login, sistem mampu memberikan keamanan terhadap data sehingga tidak sembarangan orang dapat melihat, menambah, mengubah, dan menghapus data. Halaman login juga mampu menentukan hak akses user sesuai dengan levelnya.

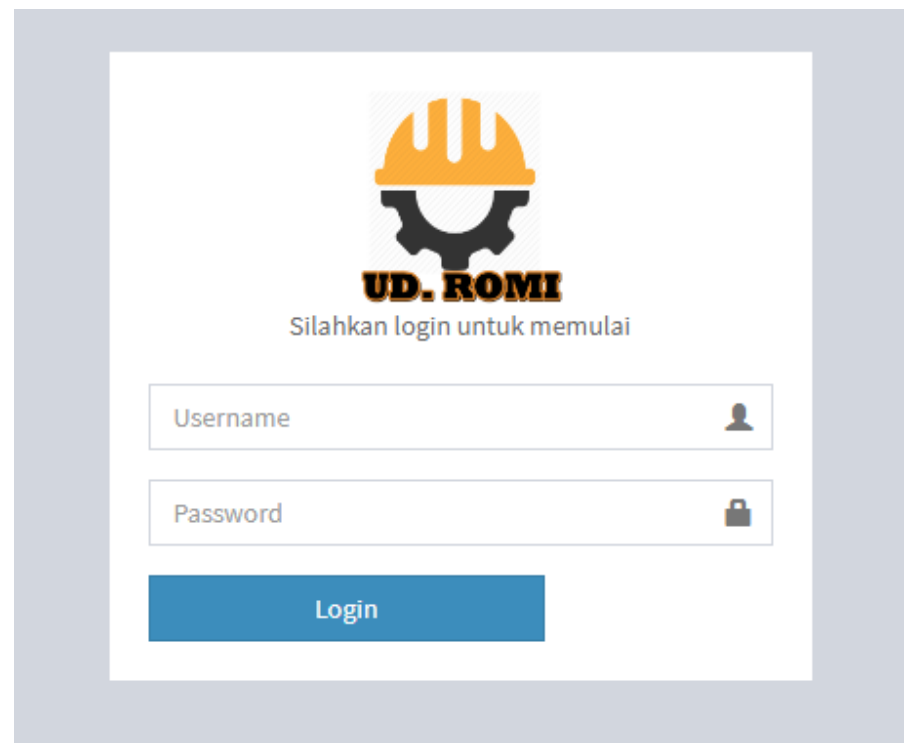

Gambar 11: Tampilan halaman login

b. Halaman input barang

Halaman input barang merupakan area dimana user dapat melakukan entri data barang pada toko UD. Romi, data yang dientrikan akan tersimpan ke dalam database.

\begin{tabular}{|c|c|c|}
\hline Home Admin & $\equiv$ & $\therefore$ Ad Administrator \\
\hline MENU & Input Barang Barang & \multirow[t]{12}{*}{ a Menu Utama = Barang : Edit Barang } \\
\hline ๑ Home & Edit Data Barang & \\
\hline Input Karyawan & Kode Barang & \\
\hline of Input Kategori & BRG0001 & \\
\hline E Transaksi & Nama Barang & \\
\hline Q Cek Barang & Semen Padang P.C.C. Hitam & \\
\hline \multirow{2}{*}{ Input Barang } & Kategori & \\
\hline & кто02 & \\
\hline Tambah Barang & Harga Awal & \\
\hline \multirow[t]{3}{*}{ - Laporan } & 53000.00 & \\
\hline & Harga Jual & \\
\hline & 60000.00 & \\
\hline
\end{tabular}

Gambar 12: Tampilan halaman input barang

c. Halaman transaksi

Halaman transaksi merupakan area dimana user dapat melakukan entri data transaksi terhadap transaksi yang dilakukan oleh pelanggan. Data barang dari setiap transaksi diambil dari data barang yang telah dientrikan sebelumnya. 


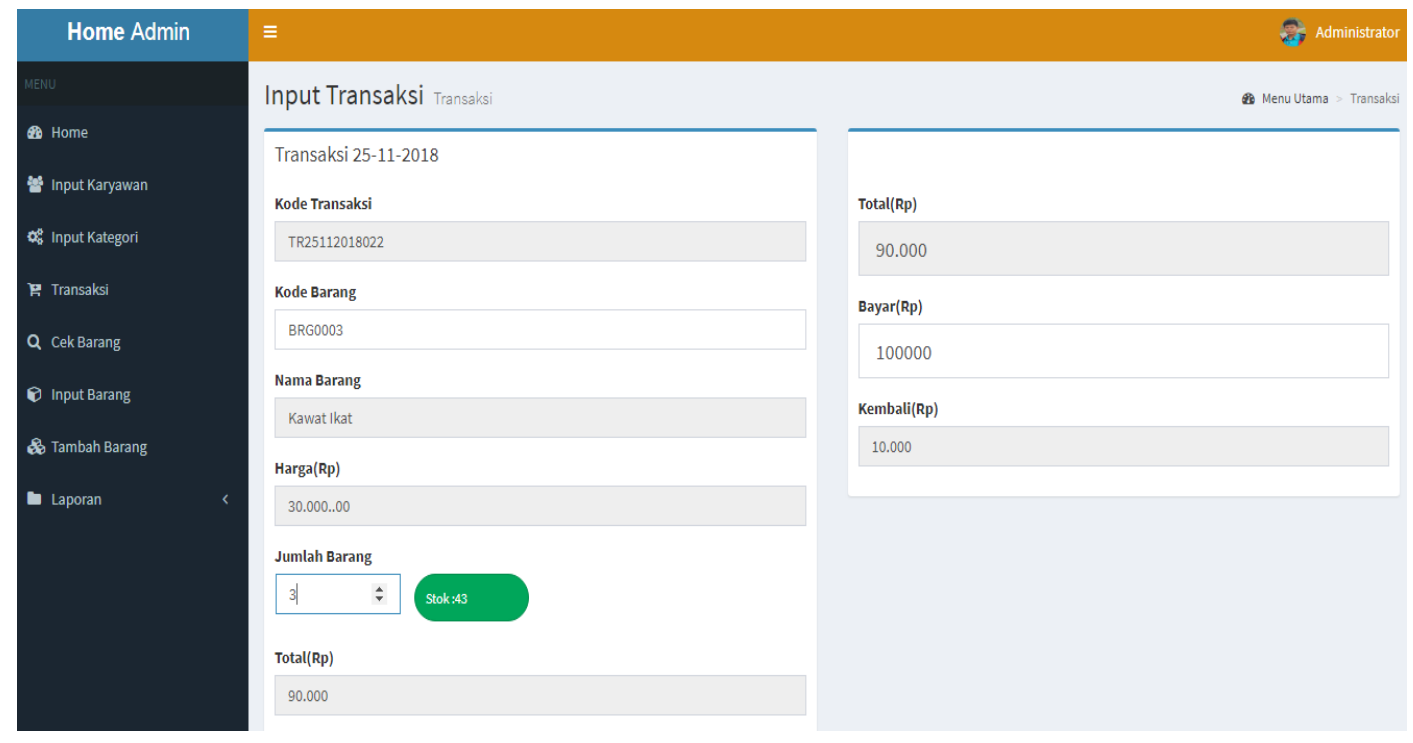

Gambar 13: Tampilan halaman transaksi

d. Laporan data persediaan barang

Laporan data persediaan barang menampilkan informasi mengenai persediaan barang pada toko UD. Romi, sehingga pimpinan dapat mengetahui informasi mengenai persediaan barang dan kebijakan apa yang harus dilakukan.

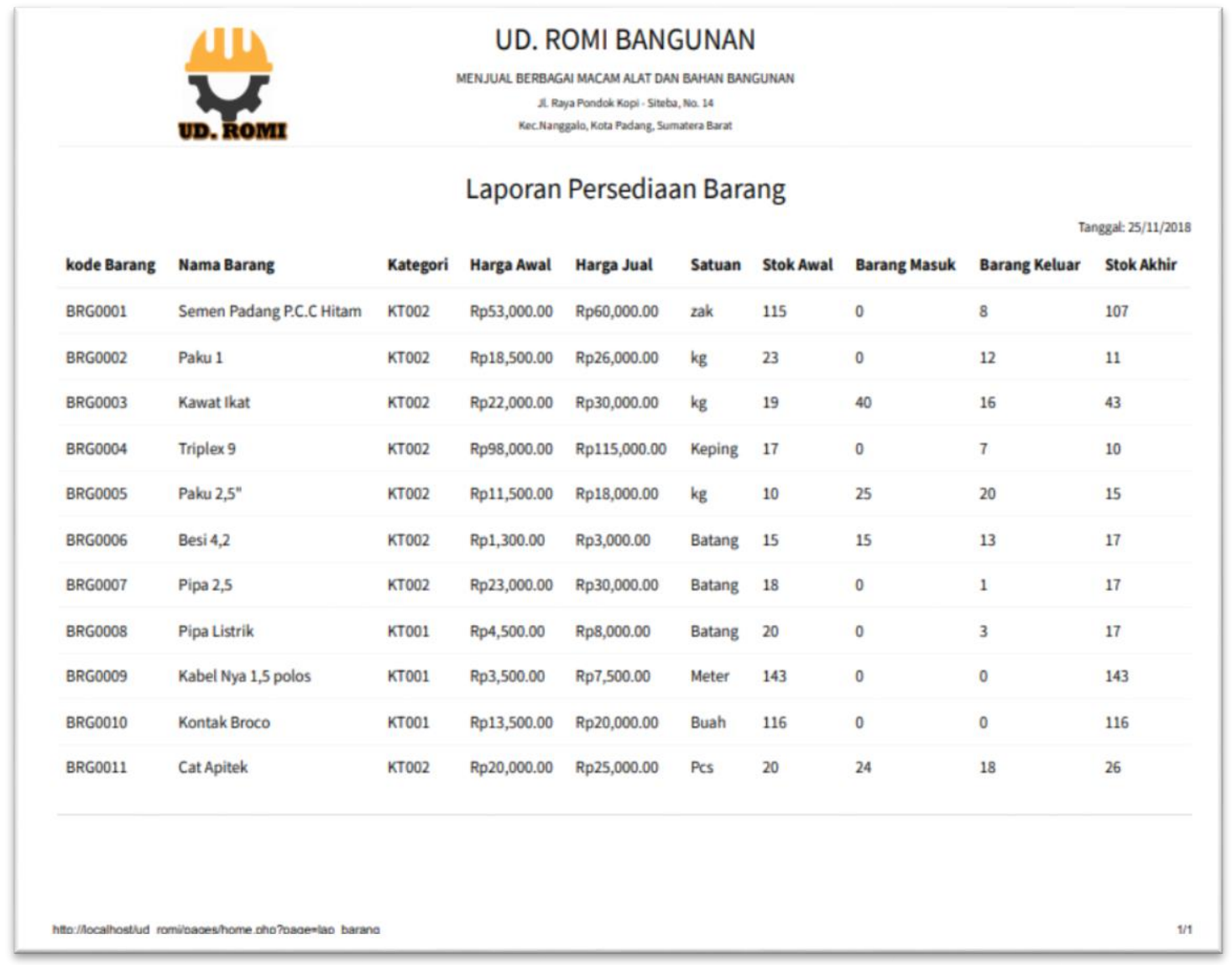

Gambar 14: Tampilan laporan persediaan barang 
e. Laporan transaksi

Laporan transaksi menampilkan informasi transaksi yang terjadi pada toko UD. Romi. Laporan transaksi dapat dicetak berdasarkan laporan harian, bulanan dan tahunan.

\begin{tabular}{|c|c|c|c|c|c|c|}
\hline \multicolumn{7}{|c|}{ 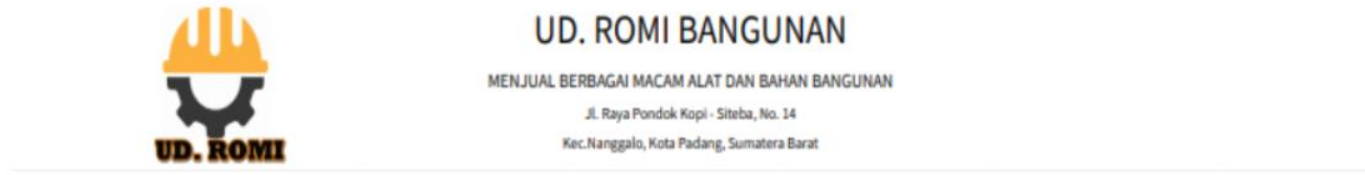 } \\
\hline \multirow[b]{2}{*}{ No } & \multirow[b]{2}{*}{ Kode Transaksi } & \multirow[b]{2}{*}{ Kode Barang } & \multicolumn{2}{|c|}{ Laporan Transaksi Tahun2018 } & \multirow[b]{2}{*}{ Jumlah Transaksi } & \multirow{2}{*}{$\begin{array}{l}\text { Tanggal: 25/11/2018 } \\
\text { Total Bayar }\end{array}$} \\
\hline & & & Nama Barang & Harga Jual & & \\
\hline 1 & TR03012018001 & BRG0003 & Kawat lkat & $R p 30,000.00$ & 1 & $\mathrm{Rp} 30,000.00$ \\
\hline 2 & TR03012018002 & BRG0003 & Kawat lkat & $R p 30,000.00$ & 3 & Rp $90,000.00$ \\
\hline 3 & TR03012018002 & BRG0001 & Semen Padang P.C.C Hitam & Rp60,000.00 & 2 & Rp120,000.00 \\
\hline 4 & TR04012018003 & BRG0003 & Kawat lkat & $\operatorname{Rp} 30,000.00$ & 1 & $\operatorname{Rp} 30,000.00$ \\
\hline 5 & TR04012018003 & BRG0001 & Semen Padang P.C.C Hitam & Rp $60,000.00$ & 2 & Rp $120,000.00$ \\
\hline 6 & TR04012018004 & BRG0002 & Paku 1 & $\operatorname{Rp} 26,000.00$ & 1 & $\mathrm{Rp} 26,000.00$ \\
\hline 7 & TR04012018005 & BRG0001 & Semen Padang P.C.C Hitam & Rp $60,000.00$ & 1 & Rp $60,000.00$ \\
\hline 8 & TR04012018005 & BRG0002 & Paku 1 & Rp26,000.00 & 2 & $\operatorname{Rp} 52,000.00$ \\
\hline 9 & TR04012018006 & BRG0002 & Paku 1 & $R p 26,000.00$ & 1 & Rp26,000.00 \\
\hline 10 & TR04012018007 & BRG0004 & Triplex 9 & Rp $115,000.00$ & 1 & Rp $115,000.00$ \\
\hline 11 & TR04012018008 & BRG0006 & Besi 4,2 & $\mathrm{Rp} 3,000.00$ & 1 & $\mathrm{Rp} 3,000.00$ \\
\hline 12 & TR04012018009 & BRG0008 & Pipa Listrik & $R p 8,000.00$ & 2 & Rp16,000.00 \\
\hline 13 & TR04012018010 & BRG0011 & Cat Apitek & $R p 25,000.00$ & 1 & $R p 25,000.00$ \\
\hline ntep $/$ /noc & 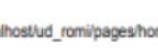 & Ppageriab_tanunsta & & & & 12 \\
\hline
\end{tabular}

Gambar 15: Tampilan halaman laporan transaksi

\section{KESIMPULAN}

Berdasarkan hasil penelitan yang telah dilakukan, maka dapat ditarik beberapa kesimpulan diantaranya yaitu dengan adanya sistem informasi transaksi dan persediaan pada toko bangunan UD. Romi, pemilik dapat menggantikan sistem lama dengan sistem terotomasi sehingga seluruh data transaksi maupun persediaan terkontrol dan tersimpan ke dalam database sehingga lebih efektif dan efisien. Tampilan sistem yang user friendly dapat mempermudah karyawan dalam memahami penggunaan sistem. Penerapan sistem lebih optimal jika sistem dihubungkan melalui jaringan LAN maupun Wireless, sehingga data dapat diakses tidak hanya pada satu komputer saja. Diharapkan untuk pengembangan sistem selanjutnya, sistem informasi ini dapat dikembangkan menjadi sebuah sistem $e$-commmerce yang dapat melakukan transaksi secara online melalui jaringan internet. 


\section{Referensi}

[1] A.S., Rosa, dan M. Shalahuddin.2015. Rekayasa Perangkat Lunak : Terstruktur dan Berorientasi Objek. Bandung: Informatika Bandung.

[2] Fowler, Martin. 2005. UML Distilled: Panduan Singkat Bahasa Pemodelan Objek Standar. Yogyakarta: Andi.

[3] Kadir, Abdul. 2010. Mudah Mempelajari Database MySQL. Yogyakarta: Andi.

[4] Kadir, Abdul, dan Terra Ch. Triwahyuni. 2013. Pengantar Teknologi Informasi Edisi Revisi 2. Yogyakarta: Andi.

[5] Marakas, George M., dan James A. O’Brien. 2017. Pengantar Sistem Informasi. Jakarta: Salemba Empat.

[6] Pratama, I Putu Agus Eka. 2014. Sistem Informasi Dan Implementasinya. Bandung: Informatika Bandung.

[7] Sidik, Betha. 2017. Pemrograman Web dengan PHP7. Bandung: Informatika Bandung.

[8] Sudarsono, B., \& Erniyanti. (2017). Perancangan Program Sistem Informasi Persediaan dan Penjualan Barang Pada Toko Sparepart Motor. Simnasiptek, 35.

[9] Tohari, Hamim. 2014. Astah Analisis Serta Perancangan Sistem Informasi Melalui Pendekatan UML. Yogyakarta: Andi 